\title{
THE INADEQUATE USE OF ANTIBIOTICS IN A GASTROENTEROLOGY DEPARTMENT
}

\author{
MARIA ADRIANA NEAG ${ }^{1}$, IOANA CORINA BOCȘAN ${ }^{1 *}$, ȘTEFAN VESA ${ }^{1}$, DANA GOȘA ${ }^{1}$, \\ ADRIAN CĂTINEAN ${ }^{2}$, GEORGIANA NAGY ${ }^{2}$, PETRU ADRIAN MIRCEA ${ }^{2}$, ANCA DANA \\ BUZOIANU $^{1}$
}

\author{
“Iuliu Hațieganu” University of Medicine and Pharmacy, Cluj-Napoca, Romania \\ ${ }^{I}$ Department of Pharmacology, Toxicology and Clinical Pharmacology \\ ${ }^{2}$ Department of Internal Medicine
}

*corresponding author: bocsan.corina@umfcluj.ro

Manuscript received: January 2018

\begin{abstract}
Antimicrobial agents are very important drugs in clinical practice, but it has been shown that these drugs are not correctly prescribed. The aim of the study consists in the evaluation of antibiotics' usage for hospitalized patients in a gastroenterology department. The therapeutic plans of 98 hospitalized patients were analysed by a specialist in clinical pharmacology. The adequate use, optimal dosage, frequency and route of administration, duration of therapy according to indications and posology mentioned in guidelines and the final cost were considered. From 184 days of hospitalization in which the patients received antibiotics, in 36 days the treatment wasn't necessary, in 69 days the doses of antibiotics were inadequate, in 2 days there were problems which should have been treated with antibiotics but they were ignored. The total cost is significantly higher $(\mathrm{p}<0.05)$ than the real cost. The incorrect use of antibiotics has a negative impact on therapy costs and patients wellbeing. The identified errors are preventable ones and did not affect the patients' quality of life.
\end{abstract}

\section{Rezumat}

Antibioticele sunt medicamente importante în practica clinică, însă s-a observat că de multe ori nu sunt corect administrate. Scopul studiului de față a fost analiza utilizării antibioticelor într-o secție de gastroenterologie. Planul terapeutic a 98 de pacienți spitalizați a fost analizat de un specialist farmacolog clinician. S-au evaluat următoarele aspecte: utilizarea adecvată, doza optimă, frecvența şi calea de administrare, durata de tratament conform recomandărilor din ghidurile terapeutice, precum și costul final al tratamentului. Din totalul de 184 de zile de spitalizare în care pacienții au primit tratament antibiotic, în 36 de zile tratamentul nu a fost necesar, în 69 de zile dozele de antibiotic au fost inadecvate, în 2 zile au fost identificate probleme ce necesitau tratament antibiotic, însă au fost ignorate. Costul total al tratamentului a fost semnificativ mai mare decât costul real $(\mathrm{p}<0,05)$. Utilizarea inadecvată a antibioticelor a avut un impact negativ asupra costului tratamentului. Erorile identificate pot fi prevenite și nu au afectat calitatea vieții pacienților.

Keywords: antibiotics, medication errors, therapy costs, clinical pharmacology

\section{Introduction}

The past century was marked by the discovery of antibiotics and the "golden age" of antibiotics usage began in 1940, together with the industrial production of penicillin [1]. Nowadays, approximately one third of the hospitalized patients benefit from antibiotic therapy and approximately $50 \%$ of antibiotic prescriptions are inappropriate or unnecessary [13]. Antimicrobial agents are very important drugs in clinical practice, they can save lives, but it has been shown that these drugs are not correctly prescribed. Sometimes they are prescribed too often or they are not necessary in some clinical conditions [25]. In comparison with other pharmacological classes, this type of drugs has the most inappropriate use in clinical practice [7], in Romania, but also in other European countries [14].
Inadequate antibiotic therapy leads to antimicrobial resistance, which represents a serious public health problem [14]. The consequences of microbial resistance are: development of other diseases, increased morbidity and mortality due to possible drug-drug interactions $[2,3,21]$, higher costs, negative impact on the health system with a major economic impact $[3,21]$. While antibiotics' correct usage represents a worldwide medical problem, despite of published international guidelines, there are variations between countries regarding their prescription [12]. Romania is among the countries with a higher volume of antibiotic prescriptions, along with Greece and Cyprus [7, 12]. There are no pharmaco-epidemiological data regarding the correct usage of antimicrobial agents in our country. A specialist in clinical pharmacology may improve the usage of antibiotics, underlying the exact conditions 
which require an antimicrobial therapy, doses and route of administration and possible drug-drug interactions. This study aims to assess the use of antibiotics among hospitalized patients in a department of gastroenterology. We assessed their indications, dosage, administration (route, timing) and costs in order to identify possible medication errors that could be prevented in further situations.

\section{Materials and Methods}

\section{Study design, site and ethical approval}

The present study was an observational, analytic, transversal one and was conducted in the gastroenterology department of the Emergency County Hospital from Cluj-Napoca, Romania, in February 2016. All patients signed an informed consent form for inclusion in the study and the study protocol was approved by the ethics committee of "Iuliu Hatieganu" University of Medicine and Pharmacy. The study was performed in accordance to the Declaration of Helsinki. Sample size, Patients

Ninety-eight patients (46 women and 52 men, with an average age of $56.4 \pm 10.3$ years), consecutively admitted in a gastroenterology department, were included in the study. Previously, the sample size was determined according to the number of patients admitted in this department every month for 2 consecutively years.

Study criteria

All hospitalized patients were included, except those admitted for diagnostic procedures only. Those were excluded from the analysis.

Definitions of medication errors and data collection A medication error was defined as "a failure in the treatment process that leads to, or has the potential to lead to, harm to the patient" [9]. Appropriateness of the correct usage (adequate use - omission error or inutile drug, optimal dosage, frequency and route of administration, duration of therapy) was analysed in accordance to existing data in summaries of products characteristics and clinical guidelines. The analysed antibiotics were recommended for treatment of urinary or respiratory tract infections, prophylaxis of infective endocarditis in high risk patients before upper or lower gastrointestinal endoscopy, prophylaxis of spontaneous bacterial peritonitis in patients with ascites,

as adjuvant treatment in patients with hepatic encephalopathy $[5,6,15,18,22,24,29]$. There were also noticed the untreated problems (a problem that could have been treated with antibiotics but it was ignored (omission errors). The diagnostic of infection was established based on microbiological examinations, but the patient was not treated with specific antibiotics during hospitalization.

\section{Criteria assessed according to the guidelines}

According to published clinical guidelines [4, 8, 10, $15,17]$ the following criteria were evaluated: adequate use in accordance with clinical guidelines, optimal dosage for recommended indications (high or low dose according to the diagnosis), frequency of administration, optimal route (oral or parenteral), duration of therapy, possible interactions of antibiotics with other drugs administered simultaneously and the final cost. The analysed expenses include: hospital cost (the cost supported by the hospital to treat the patients according to gastroenterologist recommendations) and the real cost based on correct usage of antibiotics according to international guidelines. The costs were analysed based on information about the prices published by the Romanian Health Ministry.

Statistical analysis

The day of hospitalization was the statistical unit of the study and all the parameters were related to this unit. Error distribution was calculated as the ratio between the number of days corresponding to the type of error and the total number of days corresponding to antibiotic use. Statistical analysis was performed using MedCalc Statistical Software version 19.0.3 (MedCalc Software bvba, Ostend, Belgium; 2019; www.medcalc.org). The qualitative variables were expressed as frequency and percentage and the quantitative data were characterized by mean and standard deviation. The paired samples t-test was used to compare the means. The measure of inter-rater agreement was assessed by Cohen's kappa coefficient. The level of statistical significance was set at $\mathrm{p}<0.05$.

\section{Results and Discussion}

The most commonly used antibiotics were ciprofloxacin, some beta-lactam antibiotics (amoxicillin, ampicillin, cephalosporins), rifaximin, and metronidazole.

Table I

Distribution of medication errors among patients \begin{tabular}{|c|c|c|c|}
\hline No. of days hospitalization & No. of patients with medication errors & No. of reported errors & No. of patients without errors \\
\hline 236 & $23(23.46 \%)$ & $107(58.15 \%)$ & $75(76.54 \%)$ \\
\hline
\end{tabular}

From the 98 patients included in the study, $23(23.46 \%)$ were treated with antibiotics. These 23 patients were exposed to antibiotic therapy for a total number of 184 days, with a mean value of 8 days/patient. If the errors are related to the number of days when they are produced (no matter the number of errors), there were 107 (58.15\%) days with identified errors (Table I). One type of error was recorded on a day of hospitalization, although the maximum number of errors per day that could have been was five (omission errors, wrong 
indication, wrong dose, wrong frequency and wrong treatment duration).

The medication was used correctly in 77 (41.84\%) days and unnecessary in $36(19.56 \%)$ days. In 69 (37.5\%) days the dose was inadequate and in $2(1.08 \%)$ days the antibiotic was not administered although it should have. No probable drug-drug interactions were identified. There was not an agreement between the physicians and the clinical guidelines for the correct use of antibiotics (kappa $=0.021 ; p=0.483$ ).

Table II contains examples of errors in medication and possible ways of correcting them.

Table II

Examples of medication errors and recommendation how to correct them

\begin{tabular}{|c|c|c|}
\hline Type of error & Example of error & Possible Correction \\
\hline Unnecessary drug & $\begin{array}{c}\text { The administration of a } 3^{\text {rd }} \text { generation cephalosporin (ceftriaxone) to a } \\
\text { patient with acute exacerbation of chronic pancreatitis. Liver cirrhosis } \\
\text { of unknown aetiology, most probably toxic, Child-Pugh class B }\end{array}$ & $\begin{array}{c}\text { Diagnose does not support the } \\
\text { treatment with a } 3^{\text {rd }} \text { generation } \\
\text { cephalosporin. }\end{array}$ \\
\hline Inadequate dosage & Too high or too low doses & \\
\hline Untreated problem & $\begin{array}{l}\text { During the hospitalization, the patient was clearly diagnosed (clinically } \\
\text { and biologically) with urinary infection, which remained untreated }\end{array}$ & $\begin{array}{c}\text { Antibiotic therapy } \\
\text { immediately after diagnosis }\end{array}$ \\
\hline
\end{tabular}

We have also established a relationship between each class of antibiotic or the antibiotic itself and the duration of a specific therapy (expressed in the number of days related to the total number of days of hospitalization when the patients received antibiotics). The results are presented in Figure 1. The most used antibiotics are fluoroquinolone and beta lactams (129 days - 70.1\%).

\section{\# Ciprofloxacin $\|$ Betalactams $=$ Rifaximin \\ Netilmicin = Metronidazole $=$ Gentamicin}

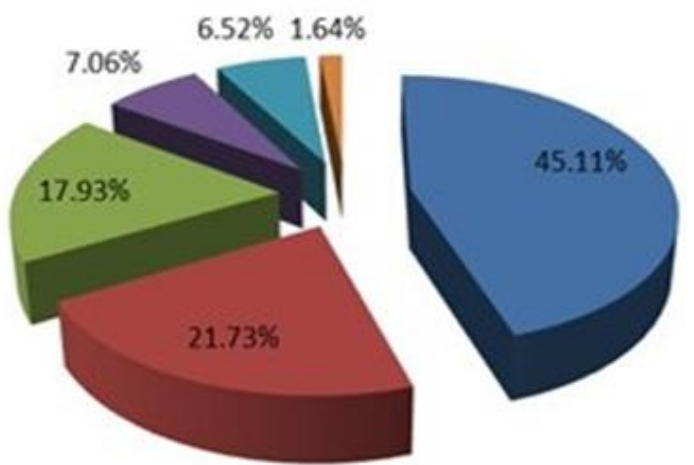

Figure 1.

Antibiotic therapy

When analysing the relationship between the administration of ciprofloxacin and the total number of patients who were treated with this drug (12 (12.24\%) patients), one can notice that it was used for $5(5.1 \%)$ patients with urinary infection, for prophylaxis in patients with liver cirrhosis and ascites (4 $(4.08 \%)$ patients), for respiratory tract infections (2 $(2.04 \%)$ patients) and for $1(1.02 \%)$ patient the treatment was unnecessary.

When analysing the relationship between the administration of ciprofloxacin and the number of days when it was administered, from a total of 83 days the antibiotic was used inadequately for 37 (44.57\%) days: incorrect dose for 29 (34.93\%) days, unnecessary for $15(18.07 \%)$ days and it could have been prescribed but it wasn't (untreated problem) for $2(2.4 \%)$ days. Therefore, ciprofloxacin was considered unnecessary when the treatment for urinary tract infections was extended (7 days instead of 5 days). Beta-lactam antibiotics, another common class of antibiotics, were administered in 10 of the 23 (43.47\%) patients. When we related the use of beta-lactam antibiotics to the number of days, they were recommended in $40(21.73 \%)$ days of antibiotic therapy. These antibiotics were mostly used (26 (65\%) out of 40 days) for prophylaxis (prevention of infective endocarditis in patients with prosthetic valve or patients with high risk for infections), for chronic pancreatitis (6 $(15 \%)$ out of 40 days) and for respiratory tract infections (8 $(20 \%)$ out of 40 days).

In what errors are concerned, the use of beta-lactam antibiotics only resulted in two errors, useless drug therapy and inadequate dosage. Concerning the number of days, the administration of beta-lactam antibiotics was useless in $12(30 \%)$ of the 40 days, and the dosage was inadequate for an equal number of days. The mean hospital cost $(1866 \pm 15.04$ euro $)$ is statistically significantly higher $(\mathrm{p}<0.05)$ than the mean real cost $(1258 \pm 10.07$ euro). The savings amount was 608 euro.

We also assessed the severity of medication errors. All of the identified errors were minor and did not influence patients' health or their quality of life.

Since antibiotics are a pharmaco-therapeutic class of drugs frequently used in hospitals, with an increased consumption in the last years, the assessment of their usage by a clinical pharmacologist was considered important. In the present study the evaluation performed by a specialist in clinical pharmacology identified several types of medication errors in hospitalized patients that could be prevented, without affecting patients' medical conditions or their quality of life. Every hospitalized patient is potentially exposed to the production of five types of medication errors related to antibiotics usage, as presented above. Every error has an equal chance of being produced. In the present study more than half of the days had an identified error (58.15\%). The errors linked to dosage (e.g. $250 \mathrm{mg} v s .500 \mathrm{mg}$ ciprofloxacin) or to uselessness 
of the drug therapy (in case of a prolonged treatment unnecessary for a specific clinical condition) were more frequently observed compared to other identified errors. These identified errors don't have a major impact on patient's safety, but can have a considerable impact on therapy costs. These were generally minor errors, but the purpose of this study was to identify the errors, not to rank them.

The errors that could have a major impact on the patients' quality of life (untreated medical issue, useless medication) appeared in only 38 days (20.65\%). A study conducted in Switzerland showed that approximately $45 \%$ of the 600 medical prescriptions analysed in 3 hospitals presented antibiotic prescription errors (dosage, route of administration, usage, treatment duration) [27]. This percentage is different from what we obtained, but they related the errors to the total number of prescriptions, while in our study the errors were reported to the total number of days, taking in account the possibility to have more than 1 error/day. On the other hand, in the aforementioned study the authors included all the errors in term of inadequate use, while in the present study we presented the errors separately.

In the present study the most frequent medication errors are linked to dosage $(37.5 \%)$. This error can be avoided if the specifications included in the summaries of products characteristics and therapeutic guidelines, which indicate the dosage for each clinical situation (urinary tract infections, acute pancreatitis and prophylaxis of spontaneous bacterial peritonitis), are strictly followed.

Less frequent errors identified in our study are the uselessness of drug therapy $(19.57 \%)$ and untreated problems $(1.09 \%)$. The uselessness of antimicrobial agents and the use of newly synthesized broad spectrum molecules in clinical situation when the compounds from older generations are still recommended, could determine an increase in resistance with a negative impact on patients and therapy costs [11].

In the present study, ciprofloxacin was one of the most widely used antibiotics (12 in 23 patients, $52.17 \%$ ), similar to other published data $[10,26]$. In relation to the number of days, ciprofloxacin was administered for 83 out of 184 days (45.1\%). In a tertiary referral hospital from Cleveland, the antibiotics were useless in $30 \%$ of all therapy days recommended, ciprofloxacin being the most frequently prescribed drug [28]. In Werner NL et al. study [28] flouroquinolones were used in 70 unnecessary regimens and in 50 necessary regimens, but for a longer time than the recommended therapy (234 vs 121 days of therapy). They investigated two types of errors (inadequate use and inadequate duration of therapy), errors that were also included in the present study.

More studies demonstrated that fluoroquinolones are often improperly used. Lautenbach et al. found that in two emergency departments, $81 \%$ of the fluoro- quinolones were improperly prescribed when related to international guidelines [16]. In a French University Hospital, Mean et al. [19] showed that $51 \%$ of the antibiotic treatment recommendations were incorrect. Similar to the mentioned studies, in the present one we identified 3 errors from the total number of 5 related to ciprofloxacin usage (incorrect dosage, useless drug or untreated problem) and 2 errors related to beta lactams (incorrect dosage, useless drug). Increased fluoroquinolone and beta lactam resistance influences patient management, as well as treatment guidelines, especially for urinary tract infections [25].

Since the total mean cost is significantly higher than the real mean cost, the errors clearly had an economic impact. According to present results 608 euro could have been saved only for 98 hospitalized patients during one month in one department. This impact is essential nowadays, as the costs of medical care continue to rise and it is necessary to establish the priorities related to health care expenses. The reduction of costs for each hospitalized patient by cutting down drug therapy expenses is an important goal not only in Romania, but also in other countries.

The Canadian Health System officials proposed a plan to improve the drug-prescribing process [23]. Thus, the actions that can influence the drug-prescribing process by the professionals from the health system should be improved, and the drugs should only be used when the problem is accurately identified (correct diagnosis), so the drug is correctly chosen and administered.

The main strength of the paper is that is presenting the first study regarding errors in antibiotics usage in Romania, trying to underline the necessity of clinical pharmacologists in order to optimize the therapy according to guidelines. O'Neil et al. suggested that a reduction in unnecessary consumption of antibiotics can have a powerful impact on resistance, especially in countries with high antibiotic consumption [20]. There are some limitations of this study. Firstly, a small number of patients were included in the study. Secondly, the authors did not evaluate the previous reactions induced by drugs in analysed data, in order to determine if the patients had risk factors for developing drugs adverse events.

\section{Conclusions}

The incorrect use of antibiotics has a negative impact, especially on therapy costs and to a lesser extent, on patient safety. The identified errors are preventable ones and did not affect patients' quality of life during hospitalization or after that. Therefore, a specialist in clinical pharmacology included in the medical team can reduce the number of errors, complying with the international guidelines. 


\section{Acknowledgement}

This work has been supported by a research grant no. 4945/15/08.03.2016 of University of Medicine and Pharmacy, Iuliu Haţieganu, Cluj Napoca, Romania.

\section{References}

1. Bentley R, Different roads to discovery; Prontosil (hence sulfa drugs) and penicillin (hence b-lactams). J Ind Microbiol Biotechnol., 2009; 36: 775-786.

2. Briciu C, Neag M, Muntean D, Vlase L, Bocsan IC, Buzoianu AD, Gheldiu AM, Achim M, Popa A, A pharmacokinetic drug interaction study between nebivolol and paroxetine in healthy volunteers. $J$ Clin Pharm Ther., 2014; 39(5): 535-540.

3. Choudhury R, Panda S, Singh DV, Emergence and dissemination of antibiotic resistance: A global problem. Ind J Med Microbiol., 2012; 30(4): 384-390.

4. Cleveland Clinic. Guidelines for Antimicrobial Usage 2012 - 2013. 2013. 82 p.

5. Dajani AS, Taubert KA, Wilson W, Bolger AF, Bayer A, Ferrieri P, Gewitz MH, Shulman ST, Nouri S, Newburger JW, Hutto C, Prevention of bacterial endocarditis: recommendations by the American Heart Association. Clin Infect Dis., 1997; 25(6): 1448-1458.

6. Eltawil KM, Laryea M, Peltekian K, Molinari M, Rifaximin $v s$ conventional oral therapy for hepatic encephalopathy: A meta-analysis. World J Gastroenterol., 2012; 18(8): 767-777.

7. Euro-Cdc. Summary of the latest data on antibiotic consumption in the European Union Antibiotic consumption in EU: 2017 (available at https://ecdc.europa.eu).

8. European Association for the Study of the Liver, EASL clinical practice guidelines on the management of ascites, spontaneous bacterial peritonitis, and hepatorenal syndrome in cirrhosis. J Hepatol Hepatol., 2010; 53(3): 397-417.

9. Ferner RE, Aronson JK, Clarification of terminology in medication errors: definitions and classification. Drug Saf., 2006; 29(11): 1011-1022.

10. Hooton TM, Uncomplicated Urinary Tract Infection. N Engl J Med., 2012; 366(11): 1028-1037.

11. Hulscher ME, Grol RP, van der Meer JW, Antibiotic prescribing in hospitals: a social and behavioural scientific approach. Lancet Infect Dis., 2010; 10(3): 167-175.

12. John Paget, Dominique Lescure, Ann Versporten, Herman Goossens, François Schellevis, Liset van Dijk. Antimicrobial resistance and causes of nonprudent use of antibiotics in human medicine in the EU. European Commission. 2017 (available at https://ec.europa.eu).

13. Karanika S, Paudel S, Grigoras C, Kalbasi A, Systematic review and meta-analysis of clinical and economic outcomes from the implementation of hospital-based antimicrobial stewardship programs. Antimicrob Agents Chemother., 2016; 22; 60(8): 4840-4852.

14. Koller D, Hoffmann F, Maier W, Tholen K, Windt R, Glaeske G, Variation in antibiotic prescriptions: is area deprivation an explanation? Analysis of 1.2 million children in Germany. Infection, 2013; 41(1): 121-127.

15. Korbila IP, Manta KG, Siempos II, Dimopoulos G, Falagas ME, Penicillins vs trimethoprim-based regimens for acute bacterial exacerbations of chronic bronchitis: meta-analysis of randomized controlled trials. Can Fam Physician., 2009; 55(1): 60-67.

16. Lautenbach E, Larosa LA, Kasbekar N, Peng HP, Maniglia RJ, Fishman NO, Fluoroquinolone utilization in the emergency departments of academic medical centers: prevalence of, and risk factors for, inappropriate use. Arch Intern Med., 2003; 163: 601-605.

17. Leekha S, Terrell CL, Edson RS, General Principles of Antimicrobial Therapy. Mayo Clin Proc., 2011; 86(2): 156-167.

18. Loomba R, Wesley R, Bain A, Csako G, Pucino F, Role of Fluoroquinolones in the Primary Prophylaxis of Spontaneous Bacterial Peritonitis: Meta-Analysis. Clin Gastroenterol Hepatol., 2009; 7(4): 487-493.

19. Mean M, Pavese P, Vittoz JP, Foroni L, Decouchon C, Stahl JP, Francois P, Prospective assessment of fluoroquinolone use in a teaching hospital. Eur $J$ Clin Microbiol Infect Dis., 2006; 25: 757-763.

20. O`Neill J, Tackling Drug-Resistant Infections Globally: Final Report and Recommendations Antimicrobial Resistance Contents, 2016 (available at https://amrreview.org).

21. Porco CT, Gao D, Scott J, Shim E, Enanoria WT, Galvani AP, Lietman TM, When Does Overuse of Antibiotics Become a Tragedy of the Commons? PLoS One, 2012; 7(12): e46505: 1-12.

22. Siempos II, Michalopoulos A, Falagas ME, Treatment of acute bacterial exacerbations of chronic bronchitis. Exp Opin Pharmacother., 2009; 10(7): 1173-1182.

23. Sketris IS, Langille Ingram EM, Lummis HL, Strategic opportunities for effective optimal prescribing and medication management. Can J Clin Pharmacol., 2009; 16(1): e103-e125.

24. Terg R, Fassio E, Guevara M, Cartier M, Longo C, Lucero R, Ciprofloxacin in primary prophylaxis of spontaneous bacterial peritonitis: A randomized, placebo controlled study. J Hepatol., 2008; 48: 774-779.

25. Ventola CE, The Antibiotic Resistance Crisis Part 2: Management Strategies and New Agents. P T., 2015; 40(5): 344-352.

26. Voicu M, Cristescu C, Zbârcea CE, Voicu A, Buda V, Suciu L, Suciu M, Proks M, Bild V, Comparative study of antimicrobials use and the antibiotic resistance of gram negative strains. Farmacia, 2017; 65(2): 225-229.

27. von Gunten V, Reymond JP, Boubaker K, Gerstel E, Eckert E, Lüthi JC, Antibiotic use: is appropriateness expensive?. J Hosp Infect., 2009; 71(2): 108-111.

28. Werner NL, Hecker MT, Sethi AK, Donskey CJ, Unnecessary use of fluoroquinolone antibiotics in hospitalized patients. BMC Infect Dis., 2011; 11: 187: $1-7$.

29. Zullo A, Hassan C, Ridola L, Lorenzetti R, Campo S, Rifaximin therapy and hepatic encephalopathy: Pros and cons. World J Gastrointest Pharmacol Ther., 2012; 3(4): 62-67. 